\title{
MYCOFLORA ASSOCIATED WITH MOMORDICA CHARANTIA L. AND THEIR PATHOGENIC POTENTIALITY
}

\author{
MD. DULAL MIYA AND SHAMIM SHAMSI* \\ Department of Botany, University of Dhaka, Dhaka-1000, Bangladesh
}

\begin{abstract}
Momordica charantia L. (Bitter gourd) is one of the popular vegetable in Bangladesh as well as in the world. After harvesting the vegetables are contaminated with fungi within 3-4 days of short storage. An investigation was carried out to find out the fungi associated with fruits of two varieties of Momordica charantia during the tenure of May 2015 to June 2016. Nine species of fungi namely, Aspergillus flavus Link, A. fumigatus Fresenius, A. niger van Tiegh, Curvularia brchyspora Boedijn, Fusarium Link, Mucor Fresen, Penicillium Link, Rhizopus stolonifer (Ehrenb.:Fr.) Vuill and Trichoderma viride Pers. were found to be associated with the selected vegetable. Aspergillus niger was predominating fungus associated with both the varieties of bitter gourd. Among the isolated 9 fungi A. niger, C. brchyspora, Fusarium sp., R. stolonifer and T. viride were found to be pathogenic to both the varieties of M. charantia.
\end{abstract}

Key words: Mycoflora, Momordica charantia, Pathogenic potentiality

\section{Introduction}

Momordica charantia, known as bitter melon, bitter gourd, bitter squash or balsam-pear is a tropical and subtropical vine of the family Cucurbitaceae. Bitter gourd are available in a variety of shapes and sizes. The cultivar common to China is 20 $30 \mathrm{~cm}$ long, oblong with bluntly tapering ends and pale green in color, with a gently undulating, warty surface. The bitter melon more typical of India has a narrower shape with pointed ends, and a surface covered with jagged, triangular "teeth" and ridges. It is green to white in color. Between these two extremes there are some intermediate forms. Some bear miniature fruit of only $6-10 \mathrm{~cm}$ in length, which may be served individually as stuffed vegetables. These miniature fruit are popular in Bangladesh, India (common name 'Korolla'), Pakistan, Nepal and other countries in South Asia.

Bitter gourd can be eaten as cooked and play an important role in human nutrition, being mostly low in fat and carbohydrates, but high in vitamins, minerals and fiber. Vegetables are rich and comparatively cheaper source of vitamins and minerals. Its consumption in sufficient quantities provides taste, palatability and increase appetite. Vegetables are currently reckoned as important adjunct for maintenance of food health and beneficial in protecting against some degenerative diseases. They also play a key role in neutralizing the acids that are formed during digestion (Ananya and Sarmistha 2010). Many people in

\footnotetext{
*Corresponding author, e-mail: prof.shamsi@gmail.com
} 
urban and rural areas fully depend on vegetable cultivation and selling in the markets. But it is the matter of deep concern that a remarkable portion of harvested vegetables are being lost due to mismanagement of the vegetables during transit and storage, as a result fungal infection occurs and consequently vegetables are spoiled. The major diseases of M. charantia are Alternaria rot (Alternaria alternata), Belly rot (Rhizoctonia solani), Cottony leak (Pythium sp.), Rhizopus soft rot (Rhizopus stolonifer), Botryodiplodia rot (Botryodiplodia theobromae) (Wikipedia 1016) etc. Haque and Shamsi (2011) reported fungal association of five vegetables in Bangladesh. So far there is no report regarding the association of fungi with fresh fruit of M. charantia in storage. Present investigation was undertaken to find out the association of fungi with M. charantia and their pathogenic potentiality.

\section{Materials and Methods}

Fruits of two varieties of Momordica charantia L. (Korolla) were used in the present investigation. One is local variety (small in size, bitter in taste) and another is a hybrid variety (larger in size, less bitter in taste). The samples were collected from five different markets of Dhaka city namely, Ananda bazar, Hatirpul bazar, Kawran bazar, Palashi bazar and Siddique bazar. Five markets were visited three times to collect the samples. From each market sufficient amount of fresh vegetables were collected randomly. Samples were collected during May to December 2015. The fungi were isolated from samples following the 'Tissue Planting Method' on PDA medium following Islam and Shamsi (2016). Identification of the isolates were determined following the standard literature (Barnett and Hunter 1972, Booth 1971, Ellis 1971, 1976, Ellis and Ellis 1997, Thom and Rapper 1945 and Rapper et al. 1949).

Per cent frequency of the occurrence of the fungal isolates was calculated by adopting the following formula (Spurr and Welty 1972):

\section{$\%$ frequency $=\frac{\text { Total numbr of inocula from which a fungal isolate was observed }}{\text { Total }} \times 100$}

All the fungi isolated from fruits of $M$. charantia were tested for their pathogenic potentiality following detached fruit assay (Shamsi et al. 2016).

Pure isolates from $M$. charantia were individually inoculated into healthy fruits of $M$. charantia at the same stage of maturity. The fungi that were isolated from $M$. charantia were grown separately on PDA medium at $\mathrm{pH} 6.0$ and temperature 25 to $28^{\circ} \mathrm{C}$ for five to seven days. The healthy vegetables were surface sterilized with $10 \%$ Chlorox and washed thrice in changes of sterilized distilled water. Then the inoculated vegetable were kept for one hour for drying.

When the vegetables were fully air dried, a cork borer $(5 \mathrm{~mm}$ diameter) was driven to a depth of $4 \mathrm{~mm}$ into the vegetables to make a groove where the isolated organism could be put. The cultured fungal isolates were also cut into round block with the help of 
another sterile cork borer (4 mm diameter) from pure PDA culture medium. Some fresh PDA blocks were also cut for the control set. Two sets of fruits of $M$. charantia were prepared where one set is control i,e, fruits inoculated with PDA blocks and another set is treated i,e, fruits inoculated with particular test pathogens. Two round grooves in local variety and three grooves in hybrid variety of $M$. charantia in suitable distance were made. Fresh PDA blocks were placed aseptically into the groove of the control set and the mycelial blocks were placed into the grooves of the treatment set. Then both the control set and the treatment set of vegetables were incubated into separate sterilized plastic boxes of suitable size. Inoculated fruits were incubated for 5 to 7 days at $25 \pm$ $2^{\circ} \mathrm{C}$. Regular observations were made and re-isolation of any pathogenic test fungi were carried out for comparison with the original fungi.

\section{Results and Discussion}

A total of nine species of fungi namely Aspergillus flavus, A. fumigatus, A. niger, Curvularia brachyspora, Fusarium sp., Mucor sp., Penicillium sp., Rhizopus stolonifer and Trichoderma viride was isolated from the fresh fruits of two varieties of $M$. charantia.

Table 1 shows eight species of fungi namely Aspergillus flavus, A. niger, A. fumigatus, Curvularia brachyspora, Fusarium sp., Penicillium sp., Rhizopus stolonifer and Trichoderma viride which were isolated from M. charantia (Local variety). Four species of fungi (Aspergillus niger, A. flavus, Penicillium sp., Rhizopus stolonifer) were isolated from the samples of Ananda bazar where frequency percentage of association of A. niger was the highest (44.) followed by Rhizopus stolonifer (26.7) and Penicillium sp. (24.3). A. flavus showed lowest mean frequency (15.7). Four species of fungi were isolated from Hatirpul bazar where frequency percentage of association of A. niger was the highest (31) followed by A. flavus (22.3) and Penicillium sp. (21). Frequency percentage of association of Fusarium sp. was lowest (15.7). Five species of fungi were isolated from the samples of Karwan bazar where frequency percentage of association of A. niger was the highest (40) followed by Trichoderma viride (20), Penicillium sp. (17.7) and Fusarium sp. (13.3). Frequency percentage of association of A. fumigatus was lowest (09). Five species of fungi were isolated from the samples of Palashi bazar where frequency percentage of association of Aspergillus niger was the highest (49) followed by Penicillium sp. (42), and A. flavus (15.7). Lowest count of $C$ brachyspora and $T$. viride (11). Five species of fungi were isolated from the samples of Siddique bazar where frequency percentage of association of Aspergillus niger was also found the highest (40) followed by A. fumigatus (20), Fusarium sp. (15.7) and Penicillium sp. (13.3\%). Frequency percentage of association of $C$. brachyspora was lowest $(11 \%)$. 
Table 1. Mean frequency (\%) of association of fungi with fruits of M. charantia (Local variety) samples collected from five different markets.

\begin{tabular}{|c|c|c|c|c|c|c|c|}
\hline \multirow{2}{*}{ Name of isolates } & \multicolumn{5}{|c|}{ Frequency $(\%)$ of fungi } & \multirow[t]{2}{*}{ Total } & \multirow[t]{2}{*}{ Mean } \\
\hline & A & $\mathrm{H}$ & $\mathrm{K}$ & $\mathrm{P}$ & $S$ & & \\
\hline Aspergillus flavus & 15.7 & 22.3 & 0 & 15.7 & 0 & 53.7 & 10.74 \\
\hline A. fumigatus & 0 & 0 & 09 & 0 & 20 & 29 & 5.80 \\
\hline A. niger & 44.3 & 31 & 40 & 49 & 40 & 204.3 & 40.86 \\
\hline C. brachyspora & 0 & 0 & 0 & 11 & 11 & 22 & 4.40 \\
\hline Fusarium sp. & 0 & 15.7 & 13.3 & 0 & 15.7 & 44.7 & 8.94 \\
\hline Penicillium sp. & 24.3 & 21 & 17.7 & 42 & 13.3 & 118.3 & 23.66 \\
\hline Rhizopus stolonifer & 26.7 & 0 & 0 & 0 & 0 & 26.7 & 5.34 \\
\hline Trichoderma viride & 0 & 0 & 20 & 11 & 0 & 31 & 6.20 \\
\hline
\end{tabular}

$\mathrm{A}=$ Ananda bazar, $\mathrm{H}=$ Hatirpul bazar, $\mathrm{K}=$ Karwan bazar, $\mathrm{P}=$ Palashi bazaar,S= Siddique bazar.

Nine species of fungi namely Aspergillus niger, A. flavus, A. fumigatus, Curvularia brachyspora, Fusarium sp., Mucor sp., Penicillium sp., R. stolonifer and T. viride were isolated from fruits of $M$. charantia Hybrid variety (Table 2). Five species of fungi were isolated from the samples of Ananda bazar where frequency percentage of association of Aspergillus niger was the highest (40) followed by Penicillium sp. (26.7), Fusarium sp. (15.3), and A. fumigatus (13.3). Frequency percentage of association of Curvularia brachyspora was lowest (11). Five species of fungi were isolated from Hatirpul bazar where frequency percentage of association of A. niger was highest (35.7) followed by Penicillium sp. (22.3), Fusarium sp. (15.7) and A. flavus (13.3). Frequency percentage of association of $R$. stolonifer was lowest (13.3). Five species of fungi were isolated from the samples of Karwan bazar where frequency percentage of association of $A$. niger was highest (40) followed by Penicillium sp. (15.7), Mucor sp. (13.3), and Fusarium sp. (11). Frequency percentage of association of A. fumigates was lowest (6.7). Six species of fungi were isolated from the samples of Palashi bazar where frequency percentage of association of A. niger was the highest (49) followed by Penicillium sp. (46.7), T. viride (22.3), Mucor sp. (11) and A. spergillus flavus (9). Frequency percentage of association of $R$. stolonifer was lowest (6.7). Six species of fungi were isolated from the samples of Siddique bazar where frequency percentage of association of A. niger was also found to be highest (46.7) followed by Fusarium sp. (20), Penicillium sp. (18), A. fumigatus (15.7), C. brachyspora (15.7) and Fusarium sp. (15.7). Frequency percentage of association of $T$. viride was lowest (11). 
Table 2. Mean frequency (\%) of association of fungi with fruits of $M$. charantia (hybrid variety) samples collected from five different markets.

\begin{tabular}{|c|c|c|c|c|c|c|c|}
\hline \multirow[t]{2}{*}{ Name of isolates } & \multicolumn{5}{|c|}{ Frequency (\%) fungi } & \multirow[t]{2}{*}{ Total } & \multirow[t]{2}{*}{ Mean } \\
\hline & A & $\mathrm{H}$ & $\mathrm{K}$ & $\mathrm{P}$ & $S$ & & \\
\hline Aspergillus flavus & 0 & 13.3 & 0 & 9 & 0 & 22.3 & 4.46 \\
\hline A. fumigatus & 13.3 & 0 & 6.7 & 0 & 15.7 & 35.7 & 7.14 \\
\hline A. niger & 40 & 35.7 & 40 & 49 & 46.7 & 211.4 & 42.28 \\
\hline C. brachyspora & 11 & 0 & 0 & 0 & 15.7 & 26.7 & 5.34 \\
\hline Fusarium sp. & 15.3 & 15.7 & 11 & 0 & 20 & 62 & 12.4 \\
\hline Mucor sp. & 0 & 0 & 13.3 & 11 & 0 & 24.3 & 4.86 \\
\hline Penicillium sp. & 26.7 & 22.3 & 15.7 & 46.7 & 18 & 129.4 & 25.88 \\
\hline Rhizopus stolonifer & 0 & 13.3 & 0 & 6.7 & 0 & 20 & 4.00 \\
\hline Trichoderma viride & 0 & 0 & 0 & 22.3 & 11 & 33.3 & 6.66 \\
\hline
\end{tabular}

$\mathrm{A}=$ Ananda bazar, $\mathrm{H}=$ Hatirpul bazaar, $\mathrm{K}=$ Karwan bazar, $\mathrm{P}=$ Palashi bazar, $\mathrm{S}=$ Siddique bazar.
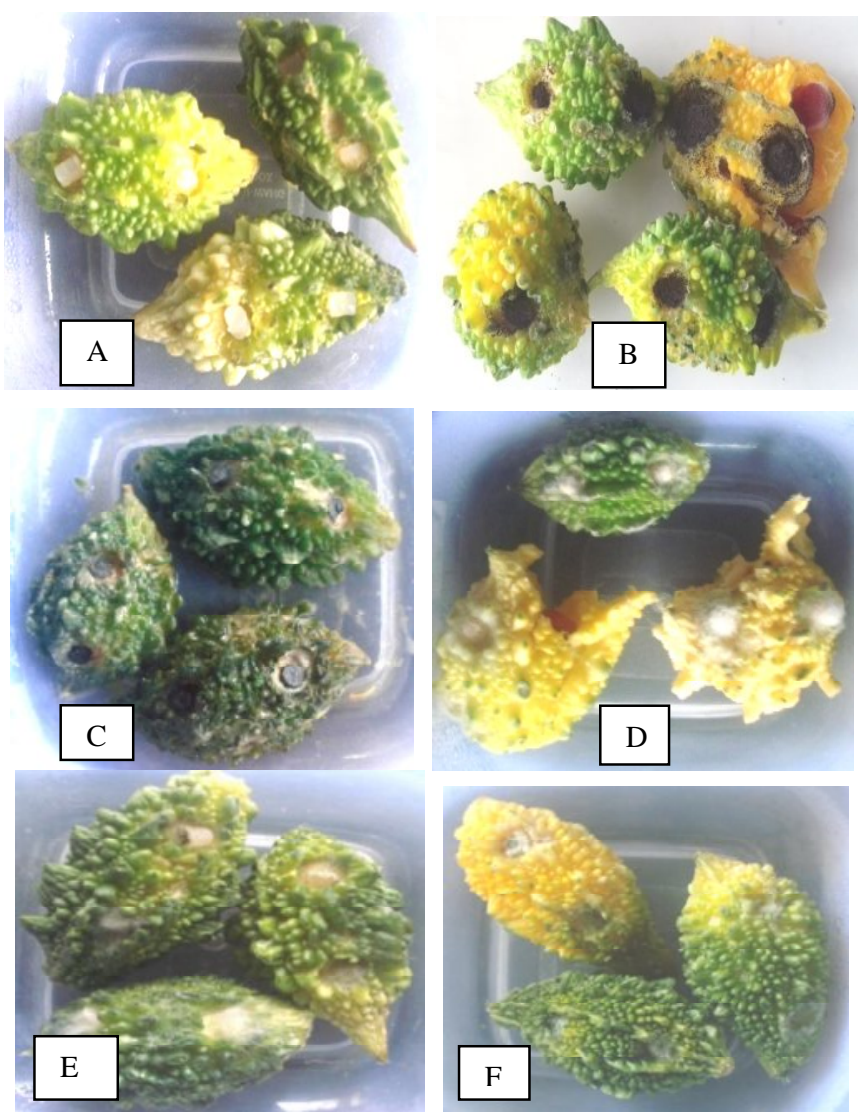

Plate 1. Fruits of $M$. charantia (Local variety) :A. control fruits; B. fruits inoculated by A. niger, C. brachyspora; D. Fusarium sp.; E. R. stolonifer and F. T. viride. 

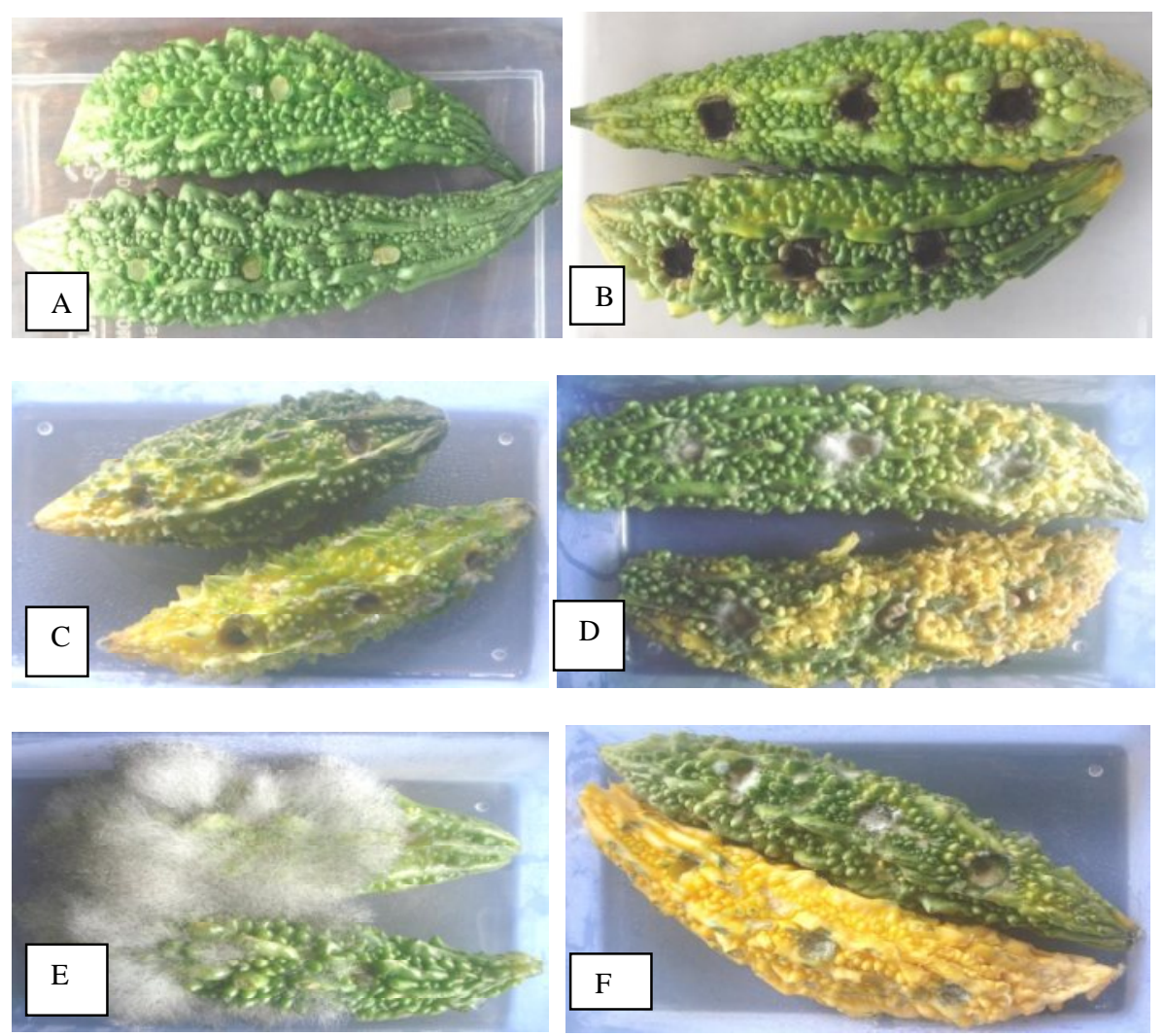

Plate 2. Fruits of M. charantia (Hybrid variety): A. control fruits, B. fruits inoculated by A. niger, C. brachyspora ; D. Fusarium sp. E. R. stolonifer and F. T. viride.

All the isolated fungi from local and hybrid variety of $M$. charantia were tested for their pathogenic potentiality. Five isolated fungi viz, A. niger, C. brachyspora, Fusarium sp., $R$. stolonifer and $T$. viride were found to be pathogenic to both the varieties of $M$. charantia. Control plate remained fresh without any fungal growth (Plates 1 and 2).

From India Mukerji and Bhasin (1986) reported fruit rot of M. charantia caused by Alternaria tenuissima (Kunze. ex Pers.), Colletotrichum lagenarium (Pers.) Ell. \& Halst, Fusarium oxysporum Schlecht ex fr., Pythium aphanidermatum (Exd.) Fitzp. and Synchytrium wurhii Rytz.

From Pakistan Sultana and Gaffar (2007) reported 29 species of fungi namely Alternaria alternate (Fr.) Keisler, A. tenuissima Kunze ex Pers. A. candidus Link., A. flavus Link \& Pers., A. niger Van Tiegh., A. tamarii Kita,Centr., A. terreus Thom, A. wentii Wehmer, Chaetomium funicola Cooke, C. globosum Kunze ex Fr., C. murorum, C. olivaceum Cook \& Ellis, Cladosporium cladosporioides (Fr.) de Vries, C. oxysporum Schlecht. 
Emend. Snyd. \& Han., C. sphaerospermum Penz., Drechslera state of Cochliobolus spicifer Nelson, F. moniliforme, F. oxysporum, $F$. semitectum, F. oxysporum. Memnoniella echinata (Riv.) Gallowany, M. verrucaria (Alb. \& Schw.) Ditm. ex Fr., Nigrospora oryzae (Berk \& Br.) Petch, Penicillium purpurogenum Stoll, Rizoctonia solani Kuhn., Rhizopus sp., Stachybotrys atra Corda, Stemphylium sp., and Trichurus spiralis as seed borne pathogen of M. charantia.

The isolated fungal pathogens reported by Mukerji and Bhasin (1986) are not found in the present investigation in Bangladesh.

Sultana and Gaffar (2007) isolated 29 species of fungi associated with seeds of $M$. charantia among which two species are same as reported in the present investigation.

In the present investigation nine fungi were associated with two varieties of $M$. charantia of which five fungi were found to be pathogenic. This is the first report on association of C. brachyspora, Fusarium sp., Mucor sp., Rhizopus stolonifer and Trichoderma viride with $M$. charantia in storage. This finding will be helpful for designing effective control measures of $M$. charantia for post harvest handling and storage.

\section{Acknowledgements}

The first author (MDM) gratefully acknowledges financial support from NST fellowship granted by 'Ministry of Science and Technology', Govt. of People's Republic of Bangladesh.

\section{References}

Ananya, P and S.R. Sarmistha. 2010. Medicinal uses and molecular identification of two Momordica charantia varieties- a review (PDF). Electronic Journal of Biology 6(2): 43-51.

Barnett, H.L. and B.B. Hunter. 1972. Illustrated Genera of Imperfect Fungi. Burgess Publishing Company, U.S.A. Third Edition. pp. 241.

Booth, C. 1971. The Genus Fusarium. Commonwealth Mycological Institute. Kew, Surrey, England. pp. 237.

Ellis, M.B. 1971. Dematiaceous Hyphomycetes. Commonwealth Mycological Institute, England. pp. 608.

Ellis, M.B. 1976. More Dematiaceous Hyphomycetes. Commonwealth Mycological Institute, England.pp. 507.

Ellis, M.B. and J.P. Ellis. 1997. Micro fungi on Land plants. An Identification Handbook. The Richmond Publishing Company Ltd. pp. 868.

Islam, A.A. and S. Shamsi. 2016. Eco Friendly Management of Mycoflora Associated with Trichosanthes Anguina L. and Trichosanthes Dioica Roxb. IJRSB. 4 (1): 52-56.

Haque, J and S.Shamsi. 2011. Study of fungi associated with some selected vegetable of Dhaka city. Bangladesh J. Sci. Res. 24(2): 181-189.

Mukerji, K. G. and J. Bhasin, 1986. Plant diseases of India. A source book. Tata Mc.Graw Hill Publishing Ltd. New Delhi. Pp.875. 
Shamsi, S., T. Saha and N. Naher. 2016. Efficacy of plant extracts and fungicides against fungi associated with lemon in storage. Bioresearch Communications. 2(1):249-253.

Sultana, N. and A. Ghaffar. 2007. Seed borne fungi associated with bitter gourd (Momordica charantia). Pak. J. Bot., 39(6): 2121-2125,

Spurr, H.W.J., and R.E.. Wetly.1972. Incidence of tobacco leaf mycoflora in relation to brown spot disease and fungicidal treatment. Phytopathology. 62:961- 920.

Rapper. K. B. and C .Thom and. L. Fennel. 1949. A Manual of the Penicillium.The Willium and Wilkins. Company, Baltimore, U. S. A. pp. 875.

Thom, C. and K. B. Raper. 1945. A. Mannual of the Aspergilli. Willium amd Wilkins, Company. Baltimore, U. S. A. pp. 373.

Wikipedia, the free encyclopedia. 2016. https://en.wikipedia.org/wiki/Momordica_charantia.

(Revised copy received on 8/8/2016) 